\title{
Analysis on the Influence of Chinese Residents' Employment on Wages
}

\author{
Dandan Qi \\ Institute of Business \& Economic Research Harbin University of Commerce, Harbin, Heilongjiang \\ Province, China 150028 \\ qidandan77777@126.com
}

Keywords: Wage income; Employment level; Urban residents

\begin{abstract}
There is a dynamic relationship between the wage and employment of urban residents in China. Wages in certain circumstances have an impact on employment, while employment in turn affect wages. Theoretical research at home and abroad about wages and employment will be summarized and analyzed wage and employment trends dynamic relationship, and then the dynamic relationship between urban wages and employment of empirical analysis. China's current situation, raise wages of urban residents not only did not cause a decline in employment levels, but cause increasing employment. This trend away from the Western mainstream theory, the reason is that there is excess labor on China's current labor market, labor surplus concentrated in the traditional industrial sector constituted by the first, resulting in this phenomenon.
\end{abstract}

\section{Research Status Analysis}

In recent years, the rapid development of China's economic level, people's living standards greatly improved, wages residents also showed a high level of growth. It has long been thought accompanied by rising wages, employment grow rapidly, data from "China Statistical Yearbook" provides the look, and not with the employment of high growth and wage growth have rapid growth. On the contrary, in recent years, according to data released by the National Bureau of Statistics, employment growth in employment and declining, it shows that the growth rate of employment in our country there have been bleaker. 2008 "New Labor Law" officially presented, where the minimum wage raised many parts of China has become the main way to solve this problem, the same time, many industries began to demand wage increases. In such circumstances, many domestic scholars speech said that minimum wage increase not only can not effectively solve the employment problem, but make the employment situation worse trend.

Chinese scholars,Professor Yuan Zhigang on the current unemployment problem gave his own understanding, put forward countermeasures, the main countermeasure is to investigate the method of world governance unemployment conclusions countries through the system. This initiative can solve China's economic growth less impact on employment levels of the status quo, can effectively improve this weak pull [1]. Dr. Liu Jun thought since 1996, China's employment elasticity gradually show a steady upward trend, reflecting China's economic growth employment absorption capacity. Also believes that the declining growth rate of employment because of statistical indicators chosen not precise enough, not even highlight the economic system of disguised unemployment a factor [2]. Currently Theoretical and Empirical Study of the dynamic relationship between academic employment and wages is still relatively small, most scholars only is the relationship between rapid economic growth and low employment situation is analyzed and the situation affect the employment of urban residents for the most direct and it should be closely real wages. This paper hopes to explore the dynamic relationship between employment growth and wage growth in the labor market in China.

\section{The Dynamic Relationship between Wages and Employment of the Three Major Industries in China}

After the reform and opening up of China's economy started a rapid development, but China is still a developing country, according to the theory of development economics, China's economy is still 
showing two of the state economy, traditional and modern departments together constitute the main body of China's economic. The traditional department in accordance with the different industries includes agriculture forestry, animal husbandry and fishery, namely, the first industry; the modern sector includes manufacturing and service industries, the second industry and the third industry. China's labor market supply and demand in the traditional and modern sectors showed a different situation, so the level of real wages in the two sector of the economy is very different from the traditional department. The economic system in a large number of surplus labor, in a way that labor force is infinite, which accord with the characteristics of the classical school wage survival theory, namely the traditional labor department A real wages barely enough to maintain the lowest living level, but the traditional sector employers can hire any labor. In the labor market of our country, efficiency wages and the equilibrium wages to the actual level of wages also has far-reaching influence. Therefore, it is only through careful observation and comparison to in-depth analysis of China's urban residents wages and employment of dynamic relationship.

\begin{tabular}{l|l|l|l|l|l|l}
\hline year & $A D A W_{1}$ & $A D A W_{2}$ & $A D A W_{3}$ & $L M_{1}$ & $L M_{2}$ & $L M_{3}$ \\
\hline 2001 & 1313.81 & 2484.81 & 2935.62 & 50.1 & 22.3 & 27.6 \\
2002 & 1475.92 & 2810.72 & 3381.87 & 50.0 & 21.5 & 28.4 \\
2003 & 1588.63 & 3214.49 & 3835.42 & 49.3 & 21.3 & 29.2 \\
2004 & 1669.79 & 3591.58 & 4184.63 & 46.4 & 22.2 & 30.5 \\
2005 & 1790.67 & 4083.81 & 4719.21 & 44.5 & 23.7 & 31.3 \\
2006 & 2002.34 & 4642.92 & 5290.67 & 42.7 & 25.3 & 32.1 \\
2007 & 2245.87 & 5157.38 & 5949.93 & 41.0 & 26.6 & 32.5 \\
2008 & 2479.14 & 5707.19 & 6569.00 & 39.7 & 27.1 & 33.3 \\
2009 & 2589.45 & 5908.76 & 6900.30 & 39.0 & 27.8 & 33.9 \\
2010 & 2677.21 & 6100.60 & 7189.21 & 38.5 & 28.2 & 34.2 \\
2011 & 2754.05 & 6377.15 & 7344.50 & 37.2 & 28.7 & 34.7 \\
2012 & 2890.15 & 6587.22 & 7490.80 & 36.5 & 29.3 & 35.1 \\
\hline
\end{tabular}

Table 1 ADAWt $(\mathrm{t}=1,2,3$, respectively, first, second and tertiary industries) represents the average wage price (CPI) after adjustment (adjusted average wage), LWt $(t=1,2,3$, respectively a first, second and tertiary industries) represents the proportion of total employment (labor weight). 1990 China's first industrial real average wage of 712.34 yuan, while in 2012 the first industry average real wage 2890.15 yuan, significantly improved significantly, only to look at the timeline of China's economy has been rapid development. However, vertical comparison of real wages three industries can be seen, in 1990 China's second and tertiary industries of real wages is $1.60,1.29$ times the first industry, that there is a certain gap between the traditional sector and the modern sector but the gap is not very big. However, in 2012 China's secondary and tertiary industries of real wages is 2.28,2.59 times the first industry doubled compared to 1990, the gap, and this gap will continue to increase in the future for a long time.

Table 1 illustrate the first industry in the proportion of employment is declining, but still accounted for the largest share in total employment. Employment in the secondary and tertiary industries accounted for total employment of the proportion of urban residents rising in 2012 can be seen from the data, the first industry employment fell to its lowest share of $36.5 \%$, but the second industry $29.3 \%$ and $35.1 \%$ compared to the tertiary industry, employment in the primary sector still holds a dominant position. From Fig. 1 and Fig. 2 can also be directly see the employment of primary industry declining, modest wage growth, while employment in secondary and tertiary industries slightly improved, significant wage growth phenomenon. This indicates that although China's economy has been greatly improved, but is still in the dual economy model. Equilibrium theory of wages in the West is still not suitable for our labor market, it can be said of the dynamic relationship between wages and employment is contrary to the theory. 


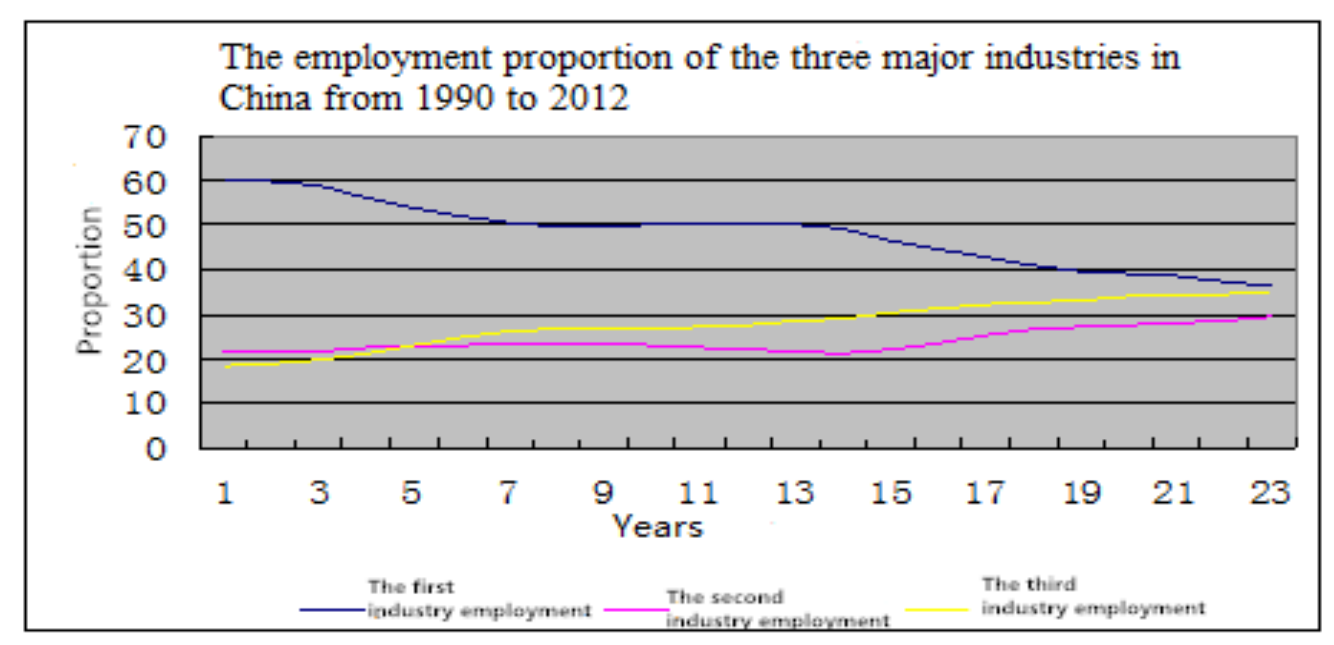

Figure 1. The employment proportion of the three major industries in China from 1990 to.2012,

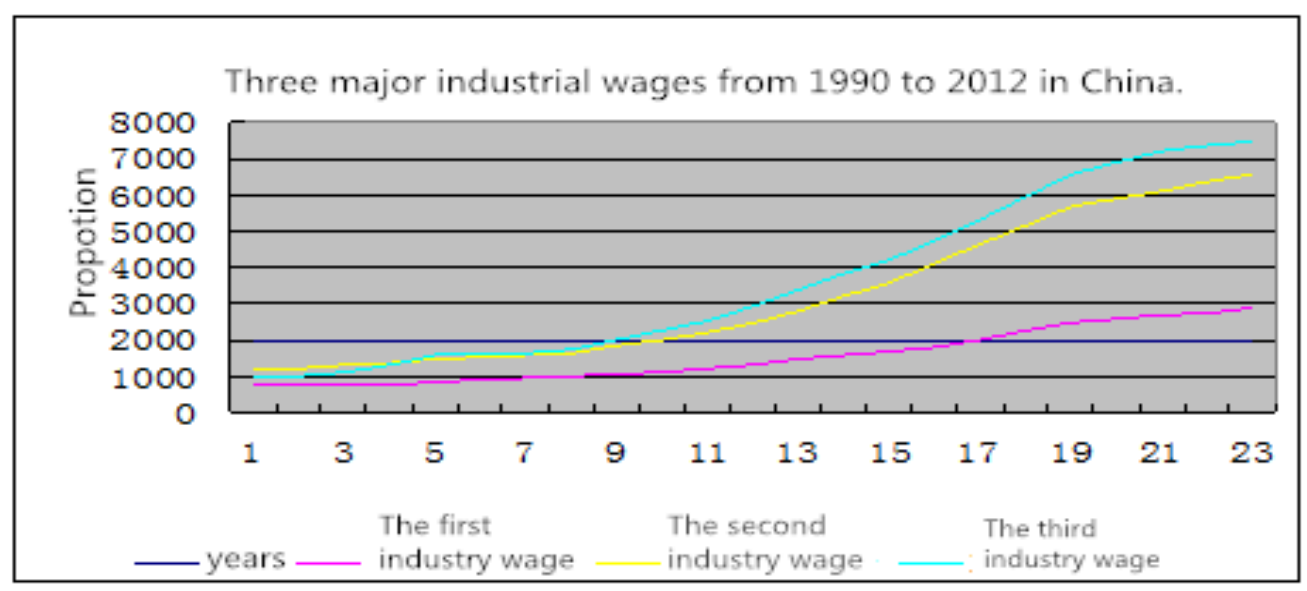

Figure 2. Three major industrial wages from 1990 to 2012 in China.

There are a large number of surplus labor department on China's traditional market, workers have only received only maintain the minimum subsistence level of wages, wages follow the theory of survival. The modern sector secondary and tertiary industries are following a balanced composition of the wage theory, the marginal revenue product of two factors on the labor supply and labor market determines the real wages of workers. Sector higher marginal revenue, limited labor supply on the market, real wages in the modern sector of higher than traditional sectors. If the labor market in free flow, the higher will be the traditional sector wages in the modern sector of the labor force to attract too much in the past, it will make employment in traditional sectors of the proportion of declining employment in the modern sector the proportion of the rise.

\section{Granger Causality Test}

The economist Clive Grainger (Clive W.J.Granger) is proposed for the analysis of the causal relationship between economic variables Grainger way. He thinks that depends on the variance optimal least squares using all information in certain time point estimation is Grainger causality. If the time series contains $\mathrm{x}, \mathrm{y}$ all the time, in this case under the test of time series of $\mathrm{Y}$ were better than those containing only tested y y point information results. The results show that the addition of $\mathrm{y}$ to the time series analysis of time series y more comprehensive future trend, in this case we think $\mathrm{x}$ is Grainger $\mathrm{y}$, if the first to Grainger test, you must first ADF unit root test and cointegration test on time series, only each time series have the same order, and between the two groups of time series The co integration relationship can be further done Grainger test, in other words, this is an essential 
prerequisite for the Grainger test, only to meet all of the above premise to carry out the Grainger test.

1. ADF unit root tests

The premise of the Granger causality test is a two time series must be for the same order integration, namely smooth. Therefore, we first use Eviews software for ADF unit root test method to verify in 2001 to 2013 urban residents wage growth rate (rate of wage growth) and employment growth rate (rate of labor growth) is the same order integration of.RWG said dweller of our country town of wage growth rate, the wage growth rate is over after a change in the price; RLG said China's urban residents employment growth rate.

Table 2, wage growth and employment growth in2001-2013. .The data comes from "China Statistical Yearbook(2001-2013)".

\begin{tabular}{c|c|c|c|c}
\hline year & ADAW & RWG & Total employed & RLG \\
\hline 2001 & 2486.92 & 0.1530 & 73032 & 0.0136 \\
2002 & 2866.11 & 0.1530 & 73747 & 0.0104 \\
2003 & 3201.08 & 0.1179 & 74439 & 0.0100 \\
2004 & 3516.15 & 0.0995 & 75207 & 0.0109 \\
2005 & 3956.95 & 0.1268 & 75832 & 0.0089 \\
2006 & 4459.17 & 0.1276 & 76407 & 0.0082 \\
2007 & 5050.89 & 0.1338 & 76997 & 0.0083 \\
2008 & 5592.12 & 0.1081 & 77487 & 0.0070 \\
2009 & 5787.45 & 0.1082 & 77690 & 0.0061 \\
2010 & 5963.21 & 0.1349 & 78340 & 0.0059 \\
2011 & 6011.03 & 0.1289 & 78860 & 0.0069 \\
2012 & 6211.45 & 0.1156 & 79240 & 0.0072 \\
2013 & 6107.82 & 0.1267 & 79950 & 0.0078 \\
\hline
\end{tabular}

Time series wage growth (RWG) of the ADF unit root test results can be calculated by Eviews6.0 metrology software, the test results shown in the following table:

Table 3 Wage growth rate ADF unit root test form from 2001 to 2012 in China Null Hypothesis: ROWG has a unit root Exogenous: Constant, Linear Trend Lag Length: 0 (Automatic based on SIC, MAXLAG=7)

\begin{tabular}{|c|c|c|c|c|}
\hline 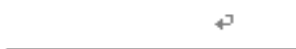 & 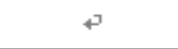 & 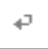 & t-Statistic & Prob.* \\
\hline \multicolumn{3}{|c|}{ Augmented Dickey-Fuller test statistic } & -3.966372 & 0.0273 \\
\hline Test critical values: & $1 \%$ level & $\$$ & -4.571559 & $\leftrightarrow$ \\
\hline 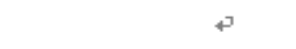 & $5 \%$ level & 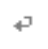 & -3.690814 & $s$ \\
\hline 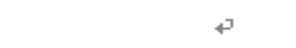 & $10 \%$ level & 5 & -3.286909 & 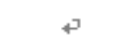 \\
\hline
\end{tabular}

According to the table can be seen that $\mathrm{P}=0.0273<0.05$, at the $5 \%$ significance level to reject the null hypothesis that there is a time series RWG unit root. This result suggests that a single time series RWG whole, and order is 0, the time series RWG is smooth. Employment growth in the same time sequence (RLG) of ADF unit root test results are calculated by Eviews6.0 metrology software, the test results shown in the following table: Granger causality test results of China's urban residents from 2001 to 2013 wage growth and employment growth, in line with the following conclusions: the continuous growth of China's economy in recent years has stimulated our efforts to expand production in various industries, such firms demand for labor continues improve. This case showed the average wage level continues to improve, while the average wage increase has brought growing 
employment in urban households. Western tradition equilibrium wage theory holds that real wage growth will cause a decline in employment levels, in our current situation, raise wages of urban residents not only did not cause a decline in employment levels, but cause increasing employment. This trend away from the Western mainstream theory, the reason is that there is excess labor on China's current labor market, labor surplus concentrated in the traditional industrial sector constituted by the first, resulting in this phenomenon. But if you want detailed description of Urban Residents' wages on employment generation, or employment of urban residents increase the degree of change in wage growth is not able to clearly describe.

\section{References}

[1] Kong Jingyuan.Theory and policy of income distribution in China[M]Beijing: China Planning Press.2005.

[2] Yang Junqing. On the rise in wages and employment incentives for workers - a model of employment different from Keynes Employment Theory[J] Chinese population science, 2005 (5)

[3] DOMS AND E.LEWIS: Labor supply and personal computer adoption,Discussion Paper, 2006

[4] LEWIS, E: How did the Miami labor market absorb the Mariel immigrants,Discussion paper, 2004

[5] Jorgenson,D.W:The Development of A Dual Economy [J],The Economic Journal 2007

[6] DOMS AND E.LEWIS: Labor supply and personal computer adoption,Discussion Paper, 2006

[7] LEWIS, E: How did the Miami labor market absorb the Mariel immigrants,Discussion paper, 2004

[8] Jorgenson,D.W:The Development of A Dual Economy [J],The Economic Journal 2007 